ORIGINAL ARTICLE

\title{
The seroepidemiology of herpes simplex virus type 1 and 2 in Europe
}

\author{
R G Pebody, N Andrews, D Brown, R Gopal, H de Melker, G François, N Gatcheva, \\ W Hellenbrand, S Jokinen, I Klavs, M Kojouharova, T Kortbeek, B Kriz, K Prosenc, K Roubalova, \\ P Teocharov, W Thierfelder, M Valle, P Van Damme, R Vranckx
}

Sex Transm Infect 2004;80:185-191. doi: 10.1136/sti.2003.005850

See end of article for authors' affiliations

.....................

Correspondence to: Dr R G Pebody, CDSC Health Protection Agency, 61, Colindale Avenue, London NW9 5DF, UK; richard.pebody@hpa.org. uk

Accepted for publication 3 October 2003

Objectives: To describe the seroepidemiology of herpes simplex virus (HSV) types 1 and 2 in the general populations of eight European countries to better understand recent reported changes in disease epidemiology.

Methods: Belgium, Bulgaria, Czech Republic, England and Wales, Finland, Germany, Netherlands, and Slovenia conducted national cross sectional serological surveys for HSV-1 and HSV-2 between 1989 and 2000. Survey sizes ranged from 3000 to 7166 sera. External quality control was ensured through reference panel testing.

Results: Large intercountry and intracountry differences in HSV-1 and HSV-2 seroprevalence were observed. Age standardised HSV-1 seroprevalence ranged from $52 \%$ in Finland, to $57 \%$ in the Netherlands, $67 \%$ in Belgium, $81 \%$ in Czech Republic, and $84 \%$ in Bulgaria. Age standardised (>12 years) HSV-2 seroprevalence ranged from $24 \%$ in Bulgaria, to $14 \%$ in Germany, $13 \%$ in Finland, $11 \%$ in Belgium, $9 \%$ in Netherlands, $6 \%$ in Czech Republic, and $4 \%$ in England and Wales. In all countries, probability of seropositivity for both infections increased with age. A large proportion of teenagers and young adults remain HSV-1 susceptible particularly in northern Europe. Women were significantly more likely to be HSV-2 seropositive in six of seven $(p<0.05)$ countries and HSV-1 seropositive in four of seven $(p<0.05)$ countries, particularly in northern Europe. No significant evidence of a protective role of HSV-1 for HSV-2 infection was found adjusting for age and sex $(p<0.05)$.

Conclusions: There is large variation in the seroepidemiology of HSV-1 and HSV-2 across Europe. The observation that a significant proportion of adolescents are now HSV-1 susceptible may have implications for transmission and clinical presentation of HSV-1 and HSV-2.

$\mathrm{H}$ erpes simplex virus types 1 and 2 (HSV-1 and HSV-2) are among the commonest human viral infections. ${ }^{1}$ Transmission is usually through intimate contact, with HSV-2 transmitted predominantly sexually and HSV-1 mainly horizontal in childhood. ${ }^{2}$ Exposure to HSV before or during birth through primary infection or reactivation can result in severe systemic neonatal infection. ${ }^{34}$

HSV-2 is of public health importance as one of the commonest causes of genital ulceration worldwide and implicated as an important co-factor for HIV infection. ${ }^{5}$ HSV-1 was associated predominantly with orolabial ulceration; however, recent changes in HSV-1 and HSV-2 epidemiology have been reported, with an increase in genital ${ }^{6-10}$ and neonatal herpes particularly caused by HSV-1. ${ }^{3-12}$ However, routine surveillance is hindered as many of those infected remain asymptomatic or fail to present to health services. ${ }^{1}$ The recent commercial development of type specific enzyme immunoassays (ELISA) that reliably distinguish between antibodies to HSV-1 and HSV-2, enable serological studies which can measure both symptomatic and asymptomatic infection. Subsequently, a small number of population based seroprevalence studies have been reported ${ }^{13-20}$; some document recent changes in the seroepidemiology of HSV-1 and HSV-2, with an increase in HSV-2 seroprevalence in some countries ${ }^{13} 1417$ and a decline in others. ${ }^{18}$ A decline in HSV-1 infection in childhood has been reported, ${ }^{15}$ with an increasing proportion of adolescents susceptible. However, some suggest these differences are the result of methodological variations. ${ }^{19}$
With several HSV candidate vaccines in clinical trial and antiviral therapy available, ${ }^{21}$ a clear understanding of the epidemiology of HSV in different populations is required to develop the most appropriate prevention and control strategies. The aim of this study was to describe seroepidemiology of HSV-1 and HSV-2 in the general populations of a variety of European countries using comparable methodology.

\section{METHODS}

National cross sectional seroprevalence surveys for HSV-1 and HSV-2 were undertaken in eight European countries: Belgium, Bulgaria, Czech Republic, England and Wales, Finland, Germany, Netherlands, and Slovenia. The England and Wales data have previously been reported. ${ }^{15}$

\section{Collection of serum banks}

Sample size calculations by age group and sex were based on estimated antibody prevalence. For HSV-1, interest focused primarily on younger age groups, where the majority of transmission occurs. The total number needed was estimated to be 4000 age stratified sera per country (200 sera per 2 year age strata from age 1-24 years and 200 sera per 5 year age strata from age 25-65 years with equal numbers in each stratum by sex). With these sample sizes, differences of $15 \%$ to $20 \%$ between age and sex subgroups in different populations should be demonstrated.

Abbreviations: CDSC, Communicable Disease Surveillance Centre; ELISA, enzyme linked immunosorbent assays; HSV, herpes simplex virus 
Sampling aimed to provide an estimate of immunity in the general population at a national level and was undertaken either by population based random sampling (four countries) or through unlinked, anonymous, residual sera submitted to laboratories for routine diagnostic purposes (four countries) (table 1). Details of the collection of these serological surveys have been previously reported..$^{152-27}$ In brief, samples were obtained from a variety of geographical locations stratified by age and sex within each country to provide a reasonably representative estimate of the general population experience. Each specimen had a unique identifier plus sex and age in completed years, the year the specimen was collected. The sole exclusion criterion was sera collected from individuals with known immune deficiencies. Sera were stored at less than $-20^{\circ} \mathrm{C}$ until tested.

In Belgium, the serum bank was residual sera from private and hospital laboratories in Flanders (five of 10 Belgian provinces-that is, $57 \%$ of the Belgian population). For the hospital samples, sera were from children and adults admitted to general surgery, traumatology, orthopaedic, and emergency units. For the private laboratories, samples were taken for screening or insurance purposes. ${ }^{22}$ In Slovenia, the serum bank was from the national, unlinked, anonymous HIV prevalence survey in pregnant women. ${ }^{23}$ In Finland, the serum bank was residual sera submitted from primary and secondary care to the two main microbiology laboratories in the country. In Bulgaria, the serum samples were from a population based survey in healthy children attending daycare centres or kindergartens; schoolchildren and students in colleges and universities, and working adults. ${ }^{26}$ In the Czech Republic, in a population based survey, 10 districts were selected at random from all 80 districts with 750 samples per district obtained across all age groups (males and females equally). From each district, 20 paediatricians or general practitioners were selected at random to identify individuals of varying ages of either sex. Individuals with known infection, antibiotic treatment, or immunodeficiency were excluded ${ }^{27}$.

The total number of sera collected by each country ranged from 3000 to 7166. Collection took place between 1989 and 2000 (table 1).

Validation and standardisation of laboratory methods To validate main serum bank testing, the Central Public Health Laboratory (CPHL), London, United Kingdom, created and distributed a panel of reference sera to each laboratory. The panel had been previously tested with an in-house reference HSV type specific blocking assay. ${ }^{28}$ The panel consisted of 88 sera including HSV-1 and HSV-2 negative, equivocal, and positive specimens. Panel testing was undertaken before and during main serum bank testing. All testing was undertaken blindly. Qualitative and quantitative results of reference panel testing were returned to CPHL.

All primary testing of reference panels was undertaken using the commercial indirect HSV-l (gGl) and HSV-2 (gG2) antibody assay, HerpesSelect (Focus Technologies, Cypress, CA, USA). The assays have previously been shown to be sensitive and specific, ${ }^{29}$ and approved by the US Food and Drug Administration (FDA). Assay kits from one manufacturing batch were bulk purchased and distributed by CPHL to all laboratories for testing the main serum banks and the reference panel.

All laboratories met kit validation criteria testing the reference panel, achieving $>90 \%$ specificity and sensitivity for both rounds compared to the consensus results for all laboratories and the reference assay results. ${ }^{30}$

\section{Main serosurvey testing strategy}

Primary testing of specimens from national serosurveys was conducted in the seven national laboratories (excluding England and Wales) with the kits as described. England and Wales tested with the in-house type specific binding ELISA assay. ${ }^{28}$ Sera from children $<12$ years were tested only with the Focus HSV-l antibody assay, and sera from $\geqslant 12$ year olds were tested with both the Focus HSV-1 and HSV-2 assays. All equivocal sera (for HSV-1 or HSV-2) and a random 5\% sample of double (HSV-1 and HSV-2) negative sera from each main serum bank, were retested at CPHL using the in-house type specific binding ELISA assay. ${ }^{15} 28 \mathrm{In}$ total, 1272 (range 12-396 per country) equivocal and 76 (range 0-22 per country) double negative sera were retested.

\section{Statistical analysis}

Data entry and analysis were undertaken using Microsoft Excel (version 9.0), Epi-Info 6.04, and Stata 6.0 software. Records of sera with missing variables were excluded. Remaining equivocals were reclassified as negative. For intercountry comparisons across age classes, direct standardisation was undertaken using the European standard population. For further intercountry comparison, the median age of acquisition was calculated for HSV-l (age group at which $50 \%$ of population were HSV-1 seropositive).

Within each country, univariable logistic regression was used to investigate the unadjusted effects of age group (0-4, $5-9,10-14,15-19,20-24,25-29,30-34,35-39,40+)$ and sex on HSV-1 and HSV-2 status. The relation between HSV-1 and

Table 1 Characteristics of national serum surveys for eight participating countries

\begin{tabular}{|c|c|c|c|c|c|c|c|c|c|}
\hline \multirow[b]{2}{*}{ Country } & \multirow{2}{*}{$\begin{array}{l}\text { Year of } \\
\text { collection }\end{array}$} & \multirow{2}{*}{$\begin{array}{l}\text { Total } \\
\text { number of } \\
\text { sera } \\
\text { collected }\end{array}$} & \multicolumn{4}{|c|}{ Age distribution of sera } & \multirow{2}{*}{$\begin{array}{l}\text { Sera sex } \\
\text { distribution } \\
\text { (male:female) }\end{array}$} & \multirow{2}{*}{$\begin{array}{l}\text { Source of } \\
\text { sera }\end{array}$} & \multirow[b]{2}{*}{ Reference } \\
\hline & & & $10-9$ years & $10-19$ years & $20-39$ years & $>39$ years) & & & \\
\hline Belgium & 1999-2000 & 3892 & 909 (23\%) & 1007 (26\%) & $988(25 \%)$ & $988(25 \%)$ & $49.1 \%: 50.9 \%$ & Residual sera & Mathei et $a^{P^{2}}$ \\
\hline Bulgaria & 1999 & 3200 & 450 (14\%) & $486(15 \%)$ & $1014(32 \%)$ & $1250(39 \%)$ & $49.7 \%: 50.3 \%$ & Population based & Gatcheva et a P $^{6}$ \\
\hline $\begin{array}{l}\text { Czech } \\
\text { Republic }\end{array}$ & 1989 & 4000 & $902(23 \%)$ & $1060(27 \%)$ & $1037(26 \%)$ & $1000(25 \%)$ & $49.9 \%: 50.1 \%$ & Population based & Kriz et $a^{P^{7}}$ \\
\hline Finland & $1997-8$ & 3346 & 779 (23\%) & 797 (24\%) & $870(26 \%)$ & $900(27 \%)$ & $53.4 \%: 46.6 \%$ & Residual sera & NA \\
\hline Germany & 1997 & 3792 & $0(0 \%)$ & $244(6 \%)$ & $1571(41 \%)$ & $1977(52 \%)$ & $50.3 \%: 49.7 \%$ & Population based $†$ & Thefeld et $a^{p^{5}}$ \\
\hline Netherlands & 1996 & 7166 & $1212(17 \%)$ & $979(14 \%)$ & $1562(22 \%)$ & $3413(48 \%)$ & $47.4 \%: 52.6 \%$ & Population based & $\begin{array}{l}\text { De Melker et } \\
a^{24}\end{array}$ \\
\hline Slovenia & 1993 & 3000 & $\begin{array}{l}0(0 \%) \\
(<10 \text { years })\end{array}$ & $\begin{array}{l}664(22 \%) \\
(10-19 \text { years) }\end{array}$ & $\begin{array}{l}2336(78 \% \\
20+\text { +years) }\end{array}$ & & $0 \%: 100 \%$ & Residual sera* & Klavs et $a^{p^{3}}$ \\
\hline $\begin{array}{l}\text { England and } \\
\text { Wales }\end{array}$ & 1994 & 4948 & $1000(20 \%)$ & $1000(20 \%)$ & $1842(37 \%)$ & $1106(23 \%)$ & $47.5 \%: 52.5 \%$ & Residual sera & Vyse et $a l^{15}$ \\
\hline
\end{tabular}


HSV-2 was also investigated in an unadjusted analysis. Country specific multivariable logistic regression was used to estimate the effect of sex adjusted for age group on HSV-1 and HSV-2 status and also to examine the interaction between age and sex. The relation between HSV-1 and HSV-2 was also investigated after adjusting for age and sex in each country. Significance was taken at the 5\% level.

\section{RESULTS}

\section{HSV-2 seroprevalence}

Four key points were noted. Firstly, HSV-2 seropositivity was widely distributed across the general populations $\geqslant 12$ years of age in the various countries by age group and sex (fig l).

Secondly, large intercountry differences in the seroepidemiology of HSV-2 were seen (fig 1): with the highest age standardised seroprevalence in Bulgaria $(23.9 \%)$ and the lowest in England and Wales (4.2\%) (in >14 year olds). Germany (13.9\%) (in >18 year olds), Finland (13.4\%), Belgium (11.1\%), Netherlands (8.8\%), and the Czech Republic (6.0\%) fell between.

Thirdly, women generally had a higher seroprevalence (and thus earlier age of acquisition) than men (fig l). In six of seven countries, (with the exception of the Czech Republic), women were significantly more likely to be HSV2 seropositive compared to males after adjusting for age group (table 2 ).

Finally, from adolescence onwards an increasing proportion in each country was HSV-2 seropositive with increasing age, with a decline in the older age groups in some countries (fig 1). Indeed, in the multivariable analysis for each country, almost all age groups were significantly more likely to be HSV-2 seropositive compared to the youngest (table 2, data not shown) adjusted for sex.

\section{HSV-1 seroprevalence}

A further four key issues were highlighted. Firstly, large differences in HSV-1 seroprevalence were observed in the general populations of the participating countries across age group and sex (fig 2). The highest age standardised HSV-1 seroprevalence in each country was observed in Bulgaria $(83.9 \%)$ and the Czech Republic $(80.6 \%)$; the lowest in Finland $(52.4 \%)$. The Netherlands $(56.7 \%)$ and Belgium $(67.4 \%)$ fell between.
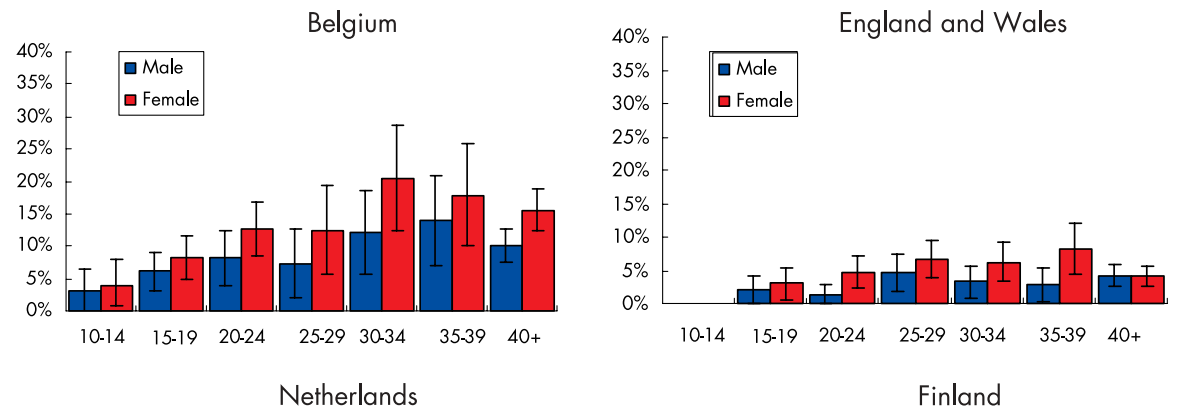

Figure 1 Age and sex specific HSV-2 seroprevalence in eight European countries with $95 \% \mathrm{Cl}$.
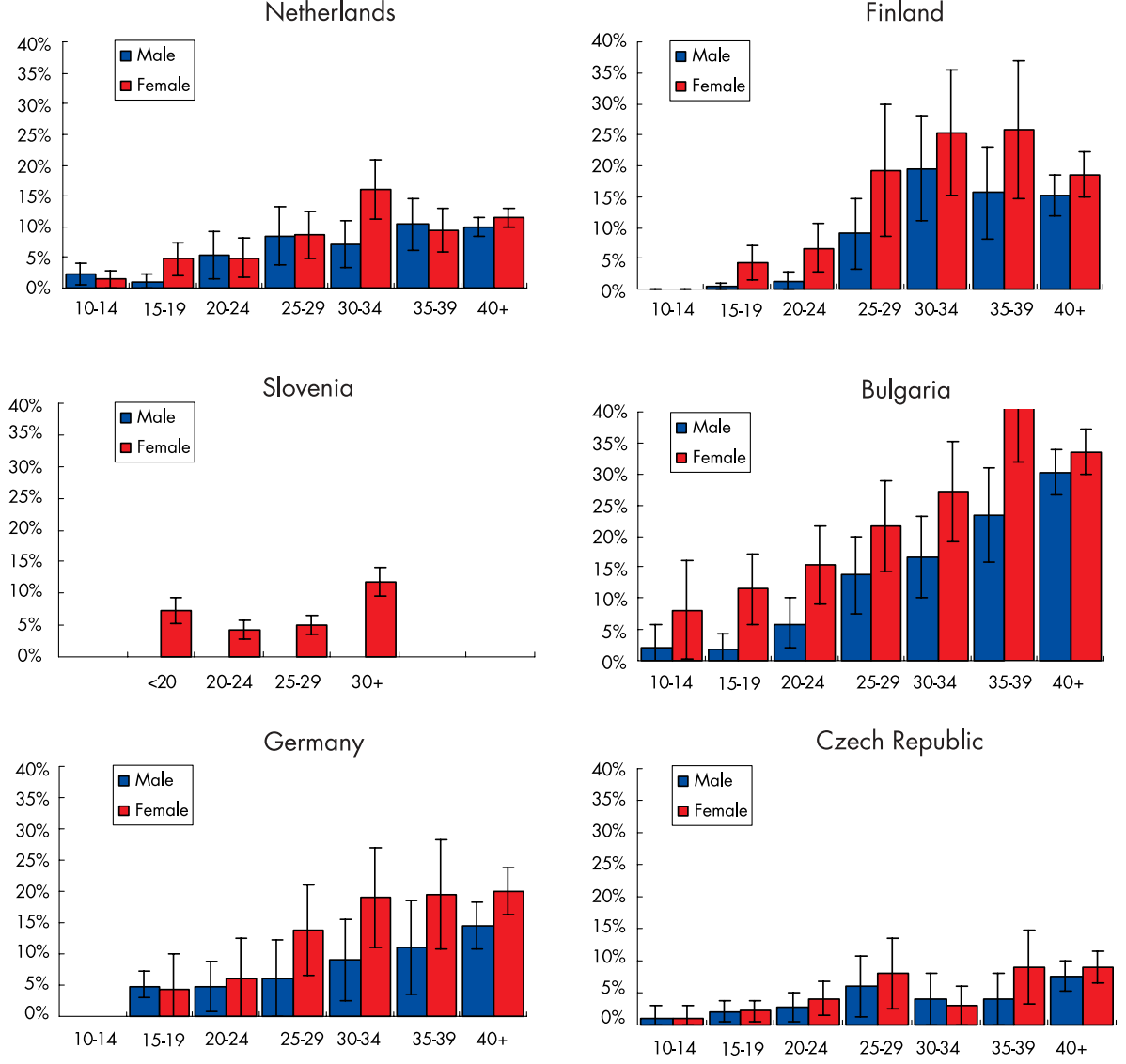
Table 2 Odds ratios for HSV-2 seropositivity ( $F: M$ OR; adjusted for age group, $95 \% \mathrm{CI}$ ) in seven European countries

\begin{tabular}{|c|c|}
\hline Country & Sex \\
\hline Belgium & $\begin{array}{l}1.59(1.24 \text { to } 2.04) \\
p<0.000\end{array}$ \\
\hline Czech Republic & $\begin{array}{l}1.26(0.90 \text { to } 1.77) \\
p=0.175\end{array}$ \\
\hline Netherlands & $\begin{array}{l}1.19(1.00 \text { to } 1.42) \\
p=0.05\end{array}$ \\
\hline Finland & $\begin{array}{l}1.64(1.26 \text { to } 2.15) \\
p<0.000\end{array}$ \\
\hline Bulgaria & $\begin{array}{l}1.51(1.25 \text { to } 1.81) \\
p<0.000\end{array}$ \\
\hline Germany & $\begin{array}{l}1.64(1.35 \text { to } 1.98) \\
p<0.000\end{array}$ \\
\hline United Kingdom & $\begin{array}{l}1.60(1.13 \text { to } 2.26) \\
p=0.008\end{array}$ \\
\hline
\end{tabular}

Secondly, in all countries, a steady increase in the proportion HSV-1 seropositive occurred with age group (fig 2). In multivariable analysis for each country, almost all age groups were significantly more likely to be HSV-1 seropositive compared to the youngest, adjusting for sex (table 3: data not shown). Furthermore, marked intercountry variation in the median age of HSV-l acquisition was observed (table 4): ranging from 5-9 years in Bulgaria and the Czech Republic to $>25$ years in Finland, Netherlands, and England and Wales. Thus, young adults in northern European countries were more likely to be HSV-1 seronegative compared to the remaining countries (table 4).

Thirdly, in four (northern European) countries (Finland, Netherlands, United Kingdom, and Germany), women were significantly more likely to be HSV-l seropositive than men after adjusting for age group (table 3 ).

Finally, males were more likely to be seronegative than females as young adults in some countries (table 4). In the multivariable analysis, the sex-age group interaction was

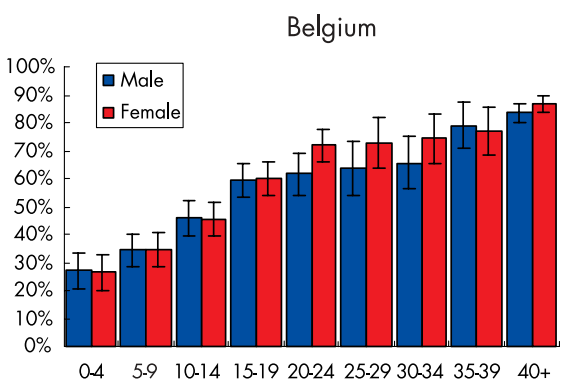

Netherlands

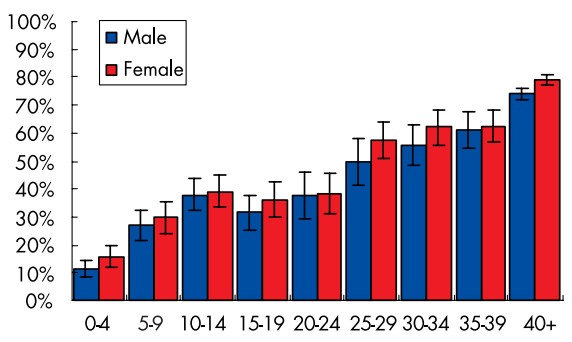

Slovenia
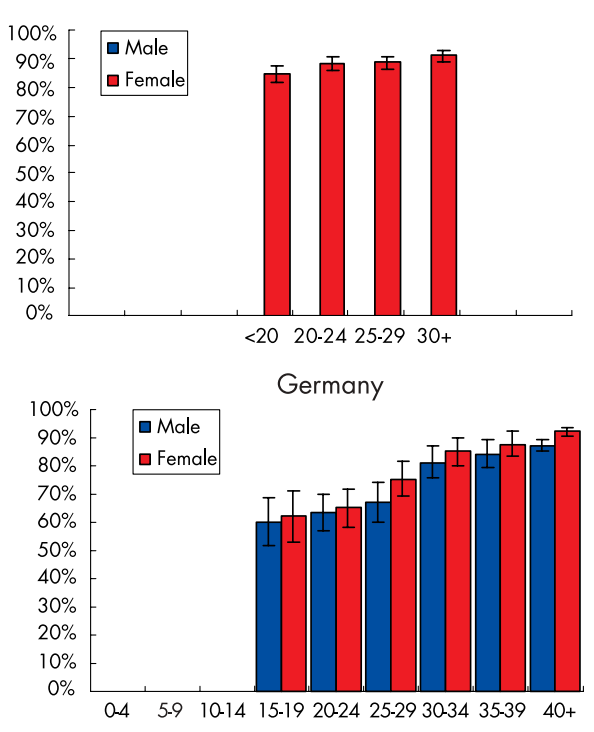

England and Wales

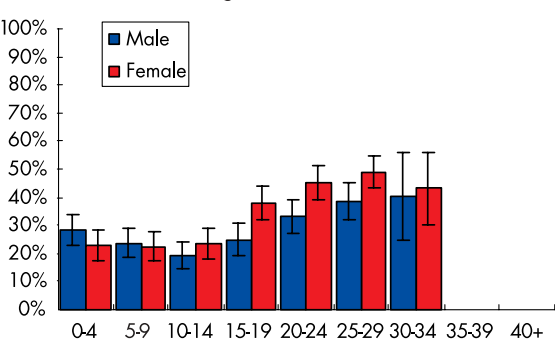

Finland

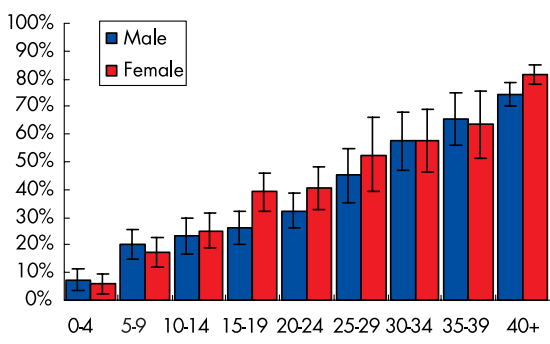

Bulgaria

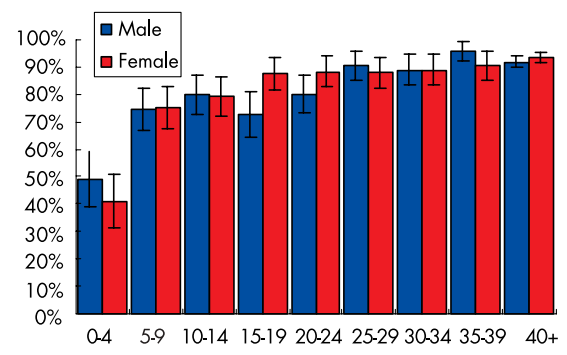

Czech Republic

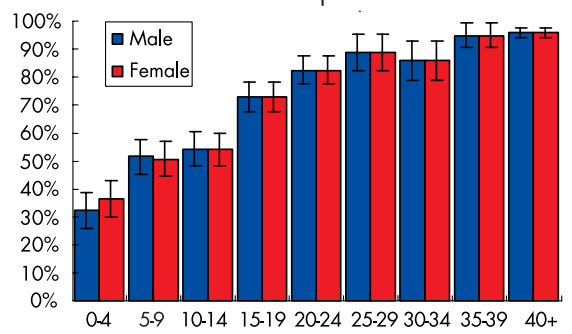

Figure 2 Age and sex specific HSV-1 seroprevalence in eight European countries with $95 \% \mathrm{Cl}$. 


\begin{tabular}{|c|c|}
\hline Country & Sex \\
\hline Belgium & $\begin{array}{l}1.14(0.99 \text { to } 1.32) \\
p=0.06\end{array}$ \\
\hline Czech Republic & $\begin{array}{l}1.15(0.98 \text { to } 1.35) \\
p=0.085\end{array}$ \\
\hline Netherlands & $\begin{array}{l}1.24(1.12 \text { to } 1.38) \\
p<0.000\end{array}$ \\
\hline Finland & $\begin{array}{l}1.28(1.09 \text { to } 1.50) \\
p=0.002\end{array}$ \\
\hline Bulgaria & $\begin{array}{l}1.12(0.91 \text { to } 1.38) \\
p=0.27\end{array}$ \\
\hline Germany & $\begin{array}{l}1.39(1.16 \text { to } 1.65) \\
p<0.000\end{array}$ \\
\hline United Kingdom & $\begin{array}{l}1.29(1.11 \text { to } 1.51) \\
p=0.001\end{array}$ \\
\hline
\end{tabular}

significant (LR test $\mathrm{p}<0.05$ ) in Bulgaria, Czech Republic, and England and Wales (table 3).

\section{Relation between HSV-1 and HSV-2}

A crude comparison of the relation between HSV-1 and HSV2 showed a positive association in four of the seven countries (table 5). After adjusting for age and sex, this association disappeared suggesting that HSV-1 and HSV-2 are both independently related to age and sex, so an unadjusted analysis gives the false impression of a relation between HSV$\mathrm{l}$ and HSV-2 positivity.

\section{DISCUSSION}

This paper is the first to our knowledge to present the comparative seroepidemiology of HSV-l and HSV-2 in Europe. To directly compare serological surveys, standardised testing and serum sampling are required. Standardised testing in this study was achieved through use of the same batch of kits and distribution of a reference panel to ensure external quality assurance. ${ }^{30}$ Sampling was either population based or through collection of residual sera. The latter method of convenience sampling has been shown to provide a good estimate of the population exposure for ubiquitous viral infections, such as measles compared to population based sampling providing sera are representative in terms of geography, age, and sex. ${ }^{81}$ However, residual sera are obtained from individuals in contact with health services, which creates a potential selection bias for a sexually transmitted infection such as HSV-2. Furthermore, serum banks were collected over a 10 year period, introducing a potential confounding effect of time. Bearing these caveats in mind, a number of conclusions can be drawn.
Firstly large intercountry and intracountry differences in HSV-2 seroprevalence were observed (from $4 \%$ to $24 \%$ overall, to $40 \%$ in some age groups), with no clear pattern according to the method of sampling or time. These figures are consistent with and in some cases exceed previous studies: HSV-2 seroprevalence in the United States has ranged from $2 \%$ in teenagers to $>25 \%$ in adults ${ }^{14}{ }^{15}$; in the United Kingdom from $2-10 \%^{8}{ }^{15}$; in Germany from $9 \%$ in pregnant women ${ }^{20}$ to $13 \%{ }^{19}$; in the general population and in Sweden from $2 \%$ at age 15 years to $25 \%$ at 30 years. ${ }^{16}$ Acquisition of HSV-2 is frequently cited as a behavioural marker, ${ }^{32}$ with HSV-2 antibody status correlated to previous sexual activity. ${ }^{32}{ }^{33}$ The differences by geography and age, we observed presumably reflect historical differences in sexual behaviour. The age effect is consistent with other studies and correlates with cumulative "sexual exposure." ${ }^{\prime 34}$ The decline in seroprevalence in the oldest age groups could reflect an age-cohort effect, with older age groups having fewer lifetime partners, ${ }^{32}$ or waning HSV-2 antibody levels. ${ }^{35}$ Whichever, asymptomatic genital shedding of HSV-2 virus plays an important part in transmission. Appropriate and effective prevention and control programmes will need to be designed to take into account these large pools of potentially infectious people.

Secondly, we demonstrated females had a consistently higher risk of HSV-2 infection compared to males in almost all countries, agreeing with previous studies. ${ }^{7131532}$ This may reflect the differential role of gender on clinical presentation, with men more likely to have asymptomatic HSV-2 infection, ${ }^{7}$ which may impact differentially on subsequent sexual behaviour and could result in higher rates of male to female transmission.

Thirdly, we observed large intercountry differences in the seroepidemiology of HSV-1. Risk of HSV-1 acquisition has been linked to sociodemographic status, ${ }^{1}$ which our study partly supports with a north-south/east gradient. Indeed, there is an inverse correlation between the age standardised seroprevalence of HSV-l and the national gross domestic product (correlation $=-0.93$ ). Thus a large proportion of adolescents remain HSV-1 susceptible in northern Europe, suggesting the age dependent force (or risk) of infection for HSV-l is higher in southern and eastern Europe than the north. These differences in HSV-1 epidemiology probably occurred recently ${ }^{15}$ and may reflect changes in socioeconomic status and family size.

Fourthly, in addition to high HSV-l susceptibility in teenage populations especially in northern Europe, the seroprofiles suggest significant HSV-1 acquisition among young adults. We were not able to estimate what proportion of those infected as young adults acquired infection orally or sexually. However, sexual transmission of HSV-l is of increasing importance particularly in northern Europe, with an increase in the proportion of genital herpes caused by

Table 4 Proportion HSV-1 susceptible by age group (years) and sex in eight European countries and median age group of HSV-1 seropositivity

\begin{tabular}{|c|c|c|c|c|c|c|c|c|c|}
\hline \multirow[b]{2}{*}{ Country } & \multicolumn{2}{|l|}{$0-9$} & \multicolumn{2}{|c|}{$10-19 *$} & \multicolumn{2}{|c|}{$20-29$} & \multicolumn{2}{|l|}{$30+$} & \multirow{2}{*}{$\begin{array}{l}\text { Median age of } \\
\text { acquisition }\end{array}$} \\
\hline & $M$ & $\mathbf{F}$ & $M$ & $\mathbf{F}$ & $M$ & $\mathbf{F}$ & $M$ & $\mathbf{F}$ & \\
\hline Belgium & $69 \%$ & $69 \%$ & $47 \%$ & $47 \%$ & $38 \%$ & $28 \%$ & $20 \%$ & $16 \%$ & $15-19$ \\
\hline Czech Republic & $57 \%$ & $56 \%$ & $36 \%$ & $29 \%$ & $16 \%$ & $17 \%$ & $6 \%$ & $5 \%$ & $5-9$ \\
\hline Netherlands & $78 \%$ & $73 \%$ & $66 \%$ & $63 \%$ & $47 \%$ & $40 \%$ & $33 \%$ & $28 \%$ & $25-29$ \\
\hline Finland & $92 \%$ & $94 \%$ & $86 \%$ & $81 \%$ & $78 \%$ & $72 \%$ & $46 \%$ & $38 \%$ & $30-34$ \\
\hline Bulgaria & $38 \%$ & $40 \%$ & $23 \%$ & $16 \%$ & $15 \%$ & $12 \%$ & $8 \%$ & $8 \%$ & $5-9$ \\
\hline Slovenia & - & - & - & $15 \%$ & - & $12 \%$ & - & $9 \%$ & - \\
\hline Germany & - & - & $40 \%$ & $38 \%$ & $35 \%$ & $30 \%$ & $14 \%$ & $9 \%$ & $<15$ \\
\hline England and Wales & $74 \%$ & $77 \%$ & $78 \%$ & $69 \%$ & $64 \%$ & $53 \%$ & $60 \%$ & $57 \%$ & $>35$ \\
\hline
\end{tabular}


Table 5 Odds ratio of HSV-1 positivity for HSV-2 positivity (OR; unadjusted and adjusted for age and sex, 95\% $\mathrm{Cl}$ ) in seven European countries

\begin{tabular}{lll}
\hline Country & OR adj* & OR unadi \\
\hline Belgium & $0.8(0.6$ to 1.1$)$ & $1.01(0.77$ to 1.32$)$ \\
Czech Republic & $0.8(0.5$ to 1.4$)$ & $1.40(0.83$ to 2.39$)$ \\
Netherlands & $0.9(0.8$ to 1.1$)$ & $1.64(1.36$ to 1.97$)$ \\
Finland & $0.8(0.6$ to 1.1$)$ & $1.51(1.16$ to 1.98$)$ \\
Bulgaria & $1.3(0.9$ to 1.9$)$ & $1.71(1.22$ to 2.39$)$ \\
Germany & $0.9(0.7$ to 1.2$)$ & $1.32(1.02$ to 1.71$)$ \\
England and Wales & $0.8(0.4$ to 1.3$)$ & $0.86(0.50$ to 1.48$)$ \\
\hline *Adjusted for age and sex. & &
\end{tabular}

HSV-1. ${ }^{911} 3637$ Recent changes in adolescent sexual behaviour, particularly the practice of oral-genital sex may partly explain this. ${ }^{9}$ Indeed, HSV-1 seropositivity in young adult populations may increasingly be a marker of higher risk sexual behaviour. ${ }^{6} 9113638$ Similar observations may be seen in the future in central and Eastern Europe.

Fifthly, we demonstrated women had a higher age specific HSV-1 seroprevalence in adolescents and young adults compared to men. The earlier increase in HSV-l seroprevalence in women seen in this study reflects the higher risk of genitally acquired HSV-1 in young women, ${ }^{79^{38-41}}$ which may reflect age specific mixing patterns, with women having male partners on average older than themselves. ${ }^{611}$ An increase in genitally acquired HSV-1 may have important "knock-on" effects: asymptomatic shedding caused by genital HSV-1 is reportedly less than HSV-2, ${ }^{42}$ and the recurrence rate lower for genitally acquired HSV-1. ${ }^{43} 44$ Any impact on vertical transmission is difficult to predict: there may be an increase in neonatal herpes as a result of increased transmission of genital HSV-1 in young women, although vertical transmission is lower for HSV-l compared to HSV $-2^{45}$ and disease is milder ${ }^{46}$ However, an increase in the proportion of neonatal herpes cases due to HSV-1 has been observed in the United Kingdom and Netherlands. ${ }^{3}$

Finally, our cross sectional study found no evidence of a protective role of HSV-1 for acquisition of HSV-2. Previous authors have produced conflicting evidence that previous HSV-1 infection reduces the risk of acquiring HSV-2. ${ }^{7}$ However, previous HSV-1 infection does modify HSV-2 clinical presentation ${ }^{47}$ and rate of subsequent recurrence. ${ }^{38}$ Thus, the observation of increased HSV-l susceptibility could result in more severe disease manifestations caused by primary HSV-2 infection and potentially increasing vertical and sexual transmission as a result of a higher rate of recurrence. These hypotheses need to be formally addressed through modelling or intervention studies.

\section{ACKNOWLEDGEMENT}

This work was supported with a grant from Glaxo-Wellcome. Parts of this paper were presented at International Congress of STI, Berlin, June 2001.

\section{CONTRIBUTORS}

The European HSV Study Group: The study was designed by RP, DB, RG and NA; RG and DB were responsible for acting as a laboratory reference centre; HM, GF, NG; WH, SJ, IK, MK, TK, BK; KP, KR, PT, $\mathrm{WT}, \mathrm{MV}, \mathrm{PD}$, and RV were responsible for collection, testing, and interpretation of national serum banks; comparative data analysis was undertaken by RP and NA; preparation of the final manuscript was coordinated by RP on behalf of NA, DB, RG, HM, GF, NG, WH, SJ, IK, MK, TK, BK, KP, KR, PT, WT, MV, PD, and RV.

\author{
Authors' affiliations \\ R G Pebody, N Andrews, Immunisation Department, Communicable \\ Disease Surveillance Centre, London, UK \\ D Brown, R Gopal, Enteric and Respiratory Viruses Laboratory, Central
}

Public Health Laboratories, London, UK

H de Melker, T Kortbeek, Centre for Infectious Disease Epidemiology, RIVM, Bilthoven, Netherlands

G François, P Van Damme, Centre for the Evaluation of Vaccination, Epidemiology and Social Medicine, University of Antwerp, Antwerp, Belgium

N Gatcheva, M Kojouharova, P Teocharov, National Centre of Infectious and Parasitic Diseases, Sofia, Bulgaria

W Hellenbrand, W Thierfelder, Department of Infectious Disease Epidemiology, Robert Koch Institut, Berlin, Germany

S Jokinen, M Valle, National Public Health Institute, Helsinki, Finland

I Klavs, K Prosenc, Department of Infectious Disease, Institute of Public Health, Ljubljana, Slovenia

B Kriz, K Roubalova, Centre of Epidemiology and Microbiology,

National Institute of Public Health, Prague, Czech Republic

R Vranckx, Scientific Institute of Public Health, Brussels, Belgium

\section{REFERENCES}

1 Nahmias AJ, Lee FK, Beckman-Nahmias S, et al. Seroepidemiological and sociological patterns of herpes simplex infection in the world. Scand J Infect Dis 1990; Suppl 69:19-36.

2 Wald A, Zeh J, Selke S, et al. Virologic characteristics of subclinical and symptomatic genital herpes infections. N Engl J Med 1995;333:770-5.

3 Tookey P, Peckham CS. Neonatal herpes simplex virus infection in the British Isles. Paediatr Perinat Epidemiol 1996;10:432-42.

4 Brown ZA, Selke S, Zeh J, et al. The acquisition of herpes simplex virus during pregnancy. N Engl J Med 1997;337:509-15.

5 Fleming DT, Wasserheit JN. From epidemiological synergy to public health policy and practice: the contribution of other sexually transmitted diseases to sexual transmission of HIV infection. Sex Transm Infect 1999;75:3-17.

6 Lafferty WE, Downey L, Celum C, et al. Herpes simplex type 1 as a cause of genital herpes: impact on surveillance and prevention. $J$ Infect Dis 2000;181:1454-7.

7 Langenberg AG, Corey L, Ashley RL, et al. A prospective study of new infections with herpes simplex virus type 1 and type 2: Chiron HSV Vaccine Study Group. N Engl J Med 1999;341:1432-8.

8 Ades A, Peckham C, Dale G, et al. Prevalence of antibodies to herpes simplex virus types 1 and 2 in pregnant women, and estimated rates of infection. $J$ Epidemiol Commun Health 1989;43:53-60.

9 Ross J, Smith I, Elton R. The epidemiology of herpes simplex types 1 and 2 infection of the genital tract in Edinburgh 1978-91. Genitourin Med 1993;69:381-3.

10 Cowan F, Johnson A, Ashley R. Relationship between antibodies to herpes simplex virus (HSV) and symptoms of HSV infection. J Infect Dis 1996; 174:470-5.

11 Lowhagen GB, Tunback P, Andersson K, et al. First episodes of genital herpes in a Swedish STD population: a study of epidemiology and transmission by the use of herpes simplex (HSV) typing and specific serology. Sex Transm Infect 2000;76:179-82.

12 Gaytant M, Steegers EA, van Cromvoirt P, et al. Incidence of herpes neonatorum in Netherlands. Ned Tijdschr Geneeskd 2000;144:1832-6.

13 Fleming DT, McQuillan GM, Johnson RE, et al. Herpes simplex virus type 2 in the United States, 1976-1994. N Engl J Med 1997;337:1 105-11.

14 Armstrong G, Schillinger J, Markowitz L, et al. Incidence of herpes simplex virus type 2 infection in the United States. Am J Epidemiol 2001; 153:912-20.

15 Vyse AJ, Gay NJ, Slomka MJ, et al. The burden of infection with HSV-1 and HSV-2 in England and Wales: implications for the changing epidemiology of genital herpes. Sex Transm Infect 2000;76:183-7.

16 Christenson B, Böttiger M, Svensson A, et al. A 15 year surveillance study of antibodies to herpes simplex virus types 1 and 2 in a cohort of young girls. $J$ Infect 1992;25:147-54.

17 Forsgren $M$, Skong $E$, Jeansson S, et al. Prevalence of antibodies to herpes simplex virus in pregnant women in Stockholm in 1969, 1983 and 1989 implications for STD epidemiology. Int J STD AIDS 1994;5:113-16.

18 Persson K, Mansson A, Jonsson E, et al. Decline of herpes simplex virus type 2 and Chlamydia trachomatis infections from 1970 to 1993 indicated by a similar change in antibody pattern. Scand J Infect Dis 1995;27:195-9. 
19 Wutzler P, Doerr H, Färber I, et al. Seroprevalence of herpes simplex virus type I and type 2 in selected German populations - relevance for the incidence of genital herpes. J Med Virol 2000;61:201-7.

20 Enders G, Risse B, Zauke M, et al. Seroprevalence study of herpes simplex virus type 2 among pregnant women in Germany using a type-specific immunoassay. Eur J Clin Microbiol Infect Dis 1998;17:870-2.

21 Bernstein D, Stanberry L. Herpes simplex virus vaccines. Vaccine 1999;17:1681-9.

22 Mathei C, Van Damme P, Bruynseels P, et al. Diphtheria immunity in Flanders. Eur Clin Microbiol Infect Dis 1997;16:631-6.

23 Klavs I, Kristančič L, Piskur-Košmač D. Unlinked anonymous HIV prevalence monitoring of pregnant women and STD patients in Slovenia in 1993. Zdrav Vestn 1994;63:659-63.

24 De Melker HE, Conyn-van Spaendonck MA. Immunosurveillance and the evaluation of national immunization programmes: a population-based approach. Epidemiol Infect 1998;121:637-43.

25 Thefeld W, Stolzenberg H, Bellach B-M. Bundes-Gesundheitssurvey: response, Zusammensetzung der Teilnehmer und Non-Responder-Analyse. Gesundheitswesen 1999;61(Suppl 2):S57-61.

26 Gatcheva N, Vladimirova N, Nenkov $P$, et al. Diphtheria serosurveillance in Bulgaria: evidence of an effective TD-revaccination of young adults. 8th International Congress on Infectious Diseases, Boston, 15-18 May, 1998:275-6 (abstract).

27 Kriz $\mathbf{P}$, Kriz B Svandova $E$, et al. Antimeningococcal herd immunity in the Czech Republic-influence of an emerging clone, Neisseria meningitides ET15/37. Epidemiol Infect 1999;123:193-200.

28 Gopal R, Gibbs T, Slomka MJ, et al. A monoclonal blocking EIA for herpes simplex virus type 2 antibody: validation for serological studies in Africa. $J$ Virol Methods 2000:87:71-80.

29 Prince HE, Ernst CE, Hogrefe WR. Evaluation of an enzyme immunoassay system for measuring herpes simplex virus (HSV) type 1-specific and HSV type 2- specific antibodies. J Clin Lab Anal 2000;14:13-16.

30 European HSV Study Group. Standardisation of HSV assays. Unpublished document.

31 Kelly H, Riddell MA, Gidding HF, et al. A random cluster survey and convenience sample give comparable estimates of immunity to vaccine preventable diseases in children of school age in Victoria, Australia. Vaccine 2002;20:3130-6.

32 Cowan FM, Johnson AM, Ashley R, et al. Antibody to herpes simplex virus type 2 as a serological marker of sexual lifestyle in populations. BMJ 1994;309:1325-9.
33 Van de Laar MJ, Termorshuizen F, Slomka MJ, et al. Prevalence and correlates of herpes simplex virus type 2 infection: evaluation of behavioural risk factors. Int $J$ Epidemiol 1998;27:127-34.

34 Johnson R, Nahmias A, Magder L, et al. A seroepidemiologic survey of the prevalence of herpes simplex virus type 2 infection in the United States. N Engl J Med 1989;321:7-12.

35 Schmid DS, Brown DR, Nisenbaum R, et al. Limits in reliability of glycoprotein G-based type-specific serologic assays for herpes simplex virus types 1 and 2 . J Clin Microbiol 1999:37:376-9.

36 Nilsen A, Myrmel $\mathrm{H}$. Changing trends in genital herpes simplex virus infection in Bergen, Norway. Acta Obstet Gynecol Scand 2000;79:693-6.

37 Scoular A, Norrie J, Gillespie G, et al. Longitudinal study of genital infection by herpes simplex virus type 1 in Western Scotland over 15 years. BMJ 2002;324:1366-7.

38 Gibson J, Hornung C, Alexander G, et al. A cross-sectional study of herpes simplex virus type 1 and 2 in college students: occurrence and determinants of infection. J Infect Dis 1990;162:306-12.

39 Peutherer JF, Smith IW, Robertson DHH. Genital infection with herpes simplex virus type 1. J Infect 1982:2:33-5.

40 Lavarty HA, Connolly JH, Russell JD. Incidence of genital herpes in Northern Ireland in 1973-83 and herpes simplex types 1 and 2 isolated in 1982-84 Genitourin Med 1986;62:24-7.

41 Barton IG, Kinghorn GR, Najern S, et al. Incidence of herpes simplex virus types 1 and 2 isolated in patients with herpes genitalis in Sheffield. $\mathrm{Br} J$ Vener Dis 1982;58:44-7.

42 Koelle DM, Benedetti J, Langenberg A, et al. Asymptomatic reactivation of herpes simplex virus in women after the first episode of genital herpes. Ann Intern Med 1992;116:433-7.

43 Lafferty W, Coombs R, Benedetti J, et al. Recurrences after oral and genital herpes simplex virus infection: influence of site of infection and viral type. N Engl J Med 1987;316:1444-9.

44 Benedetti JK, Zeh J, Corey L. Clinical reactivation of genital herpes simplex virus infection decreases in frequency over time. Ann Intern Med 1999:131:14-20.

45 Brown Z, Selke S, Zeh J, et al. The acquisition of herpes simplex virus during pregnancy. N Engl J Med 1997;337:509-15.

46 Forsgren M, Malm G. Herpes simplex virus and pregnancy. Scand J Infect Dis Suppl 1996;100:14-19.

47 Nahmias AJ, Josey WE, Naib ZM, et al. Antibodies to herpesvirus hominis types 1 and 2 in humans. Patients with genital herpetic infection. Am J Epidemiol 1970;91:539-46. 